MedieKultur | Journal of media and communication research | ISSN 1901-9726

Article - Open section

\title{
Fra monteret monolog til direkte dialog
}

\author{
Freja Sørine Adler Berg
}

MedieKultur 2016, 144-164

Published by SMID | Society of Media researchers In Denmark | www.smid.dk The online version of this text can be found open access at www.mediekultur.dk

\begin{abstract}
UK]
This article investigates the development of the form in public service talk radio from the closure of the documentary department in DR (Danish Broadcast Corporation) in 2007 to the arrival of the public service radio station Radio24/7, established in 2011 to renew the overall supply of radio programming. A content analysis of P1 (DR's talk radio channel) and Radio24/7 shows a significant drop in reading, reporting, location broadcast, and edited, artistic genres, such as radio drama and documentary. Compared to 2007, P1 broadcasts twice as much studio and telephone interviews in 2015. Likewise, Radio24/7 also broadcasts a large number of studio interviews with almost no edited, artistic programs. The Radio24/7 broadcasts contain twice as much dialogue as $\mathrm{P} 1$, although the latter has also recorded a minor increase in the dialogue form. The article explains the reasons for this development, and argues that the increase of studio programs reflects the public service institutions' prioritization of journalistic content over exploring the media's aural possibilities, while it also reflects the downgrading of importance of creating programs with high production value.
\end{abstract}

\section{Abstract (DK)}

Siden nedlaggelsen af montageafdelingen i DR i 2008 har dansk public servicetaleradio veret kritiseret for at mangle kunstneriske ambitioner. I artiklen bliver det dokumenteret, at P1 og Radio24syv vagter aktualitet, lytterengagement og lyt- 
terinteraktivitet over de tidskrcevende, monterede formater. Den kvantitative indholdsanalyse af en uges programmer i 2007 og 2015 viser et fald i formidlingsformer som oplaesning, reportage, interviews uden for studiet, dokumentar og drama. Dertil måles en stigning i studieinterviews og dialog. Gennem en dokumentanalyse vurderes det, at både DR og Radio24syv ønsker at vaere brede og modtagerorienterede. Det konkluderes, at der er sket en ensretning af formidlingsformerne siden 2007, og at public service-taleradioen i den forstand er blevet mere smal i dens udbud. Artiklen er samtidig et metodisk eksempel på, hvordan man kan arbejde kvantitativt med radiooutput.

\section{Indledning}

Verden har de sidste par år oplevet en stigende interesse for taleradioen. Den amerikanske podcast 'Serial', der er blevet hentet mere end fem millioner gange på iTunes (Andersen, 2014), beviste, at formatets øgede tilgængelighed i globaliseringens tidsalder kan tiltrække nye lyttere $i$ hobetal på linje med amerikanske tv-serier. Herhjemme tyder succesfulde tiltag som 'Københavns Radiobiograf' på, at radio i dag kan anvendes som en kunstform, der tages seriøst. Ikke mindst teknologien har været fordelagtig for det gamle medie og skabt en mangfoldighed af lytteroplevelser. Men den stigende konkurrence fra private og udenlandske podcastproducenter og et mere og mere fragmenteret publikum (Anderson, 2006, p. 2) stiller også krav til public service-institutionerne om fornyelse. Derfor kan man med rette forholde sig til, om der i den digitale netværksæra ses nye formmæssige tendenser i dansk public service-taleradio.

Besparelserne i DR, som medførte lukningen af montageafdelingen fra årsskiftet 2008, startede en bølge af kritik af public service-taleradioens kunstneriske ambitioner - eller mangel på samme (Brandt, 2007; Strand et al., 2007). Siden da er konkurrencesituationen kun blevet hårdere, blandt andet på grund af den privatejede og licensfinansierede radiostation Radio24syv, der blev skabt med det formål at skabe større mangfoldighed på radioområdet (Kulturministeriet, 2010a, p. 4). Radio24syv skulle fremtidssikre dansk taleradio ved at genopdage radiomediets muligheder og være førende på innovation, formidling og teknologi. Konkurrencen fra en ny taleradiokanal skulle med andre ord også virke fornyende på DR's programflade, nærmere bestemt P1, DR's indholdsformaterede talekanal. Men har Radio24syv levet op til ambitionerne om at udvikle den danske taleradio? Og i så fald hvordan?

Jeg vil i denne artikel undersøge, hvordan formidlingsformerne i dansk public servicetaleradio har udviklet sig siden DR's spareplan med start i 2008 og Radio24syvs tilkomst i 2011. Jeg vil desuden diskutere, hvordan udviklingen kan forklares i både et institutionelt, et regulativt og et teknologisk perspektiv. Da der ikke er foretaget en lignende undersøgelse i eller uden for Danmark, vil artiklen vægte undersøgelsens fremgangsmåde og resultater frem for den sparsomme teori og litteratur på taleradioområdet. 


\section{Undersøgelsens fremgangsmåde}

Denne artikel tager udgangspunkt i to metodiske analyser. For det første en kvantitativ indholdsanalyse af en uges programmer på P1 i 2007 og en uges programmer på P1 og Radio24syv i 2015, hvilket har til formål at diskutere formidlingsformernes udvikling. Undersøgelsens kodningsdesign og kodeskema er inspireret af Nete Nørgaard Kristensen og Christine Lejres artikel 'En kvantitativ metode til analyse af radio' i Mediekultur Vol 30, No 56. Den beskrevne metode har de fordele, at den giver mulighed for at kode på indslagniveau og ikke blot på programniveau, og at kodningskategorierne (og dermed formidlingsformerne) opstår efterhånden, som programmerne bliver lyttet igennem, frem for, at forskeren på forhånd skal "opfinde" et system af kategorier.

Af flere grunde er den kvantitative indholdsanalyse en effektiv måde at undersøge hvad, der kommunikeres. Den giver mulighed for at danne sig et repræsentativt overblik over en given datamængde uden at skulle forholde sig udtømmeligt til hele datamængden, og den kan give et blik på udviklingen af et fænomen over en længere årrække. Desuden er den kvantitative indholdsmetode kendetegnet ved at være nonreaktiv, hvilket vil sige, at dataindsamlingen ikke i sig selv påvirker det empiriske materiale (Eskjær \& Helles, 2015, pp. 12-19).

Dernæst tager artiklen udgangspunkt i en kvalitativ analyse af eksisterende dokumenter, der har til hensigt at levere et induktivt blik på resultatet af den kvantitative indholdsanalyse samt at bidrage med basal information om de involverede institutioner, det vil sige DR, Radio24syv og Kulturministeriet. Dokumentanalysen har altså til formål at fremlægge de krav, der stilles til public service-taleradioen, samt hvordan de forskellige aktører mener, at P1 og Radio24syv skal opfylde disse krav.

Metodekombinationen har til formål at opnå en bredere og mere dybdegående indsigt i udviklingen af formidlingsformerne i dansk public service-taleradio år 2007-2015. Formålet er derfor ikke at "krydstjekke" undersøgelsens resultater med henblik på at højne reliabiliteten, men at opnå mulighed for at sammenholde den kvantitative indholdsanalyses resultater med de institutionelle beslutninger.

I det følgende vil jeg gå i dybden med, hvordan de to metoder fungerer konkret i undersøgelsen, hvad angår udvælgelsen af dokumenter, sampling og afgrænsning af det radiofoniske materiale og endelig udviklingen af kodningskategorier.

\section{Udvalgelse og analyse af dokumenter}

Dokumenterne, der udgør undersøgelsens primære litteratur, kan deles op i fire former for kildemateriale: Lovgivning (Kulturministeriet som afsender), publikationer (Kulturministeriet, DR, Radio24syv som afsendere), pressemeddelelser (Kulturministeriet, DR, Radio24syv som afsendere) og avisartikler ( $\mathrm{fx}$ Politiken og Information som afsendere). Alle dokumenter indeholder en klar markering af, hvem afsenderen er, og hvad intentionen bag dokumentet er, og de er blevet gennemgået systematisk for hvert emne eller område, der fokuseres på i analysen. Når der for eksempel ønskes svar på, hvordan DR og Radio24syv formelt forhol- 
der sig til lytterinteraktion, vil samtlige dokumenter indeholdende information herom blive gennemgået.

Udvælgelsesrammen for dokumentanalysen er samtlige public service-kontrakter og -redegørelser mellem 2007 og 2015 samt andre officielle, eksterne publikationer fra public service-institutionerne og Kulturministeriet (herunder Kulturstyrelsen), som vedrører institutionelle beslutninger i dette tidsrum. Alle dokumenter kan findes på DR's, Radio24syvs og Kulturministeriets hjemmesider.

DR's public service-kontrakt og public service-redegørelse fra 2007 til 2015 beskæftiger sig kun overfladisk med P1 som kanal og er derfor kun relevante i forhold til at belyse DR og Kulturministeriet som institutioner i deres helhed. Radio24syvs public service-kontrakt og -redegørelse leverer til gengæld et dybdegående indblik i prioriteringen af formidlingsformerne.

Alle dokumenter - public service-redegørelser, public service-kontrakter, pressemeddelelser og journalistisk materiale - behandles med det forbehold, at de har en legitimerende funktion for den pågældende institutions handlinger, og at afsenderen kan have en politisk agenda.

\section{Sampling}

Populationen udgøres af de to public service-taleradiokanaler inden for udvælgelsesrammen 2007-2015 af DR P1 (uge 8 2007, uge 8 2015) og Radio24syv (uge 8 2015). Udgangspunktet for undersøgelsens udvælgelsesmetode er en fortløbende uge, hvor alle uger inden for undersøgelsesperioden har lige stor sandsynlighed for at blive valgt, såfremt de ikke er mærket af særlige begivenheder eller højtider, som påvirker undersøgelsesresultaterne i afgørende grad (Eskjær \& Helles, 2015, p. 54).

Men en sandsynlighedsbaseret udvælgelse medførte i denne undersøgelse to uhensigtsmæssige konsekvenser. For det første risikerede undersøgelsen at blive uaktuel. Public service-institutionerne træffer hele tiden nye beslutninger, som for eksempel P1's beslutning om fra efteråret 2014 at sende live mellem kl. 6 og 18 på alle hverdage, og i foråret 2015 blev radiodramaet fjernet fra kanalens sendeplan. Derfor er aktualitetskriteriet vægtet højere end en sandsynlighedsbaseret, tilfældig udvælgelse.

Dermed endte uge 82015 med at blive udvalgt. For at gøre udvælgelsen systematisk er stikprøven fra før 2008 foretaget i samme ugenummer (uge 8 2007). Ingen af disse uger er mærkede af særligt markante omstændigheder eller begivenheder, som kan medføre tilfældige fejl i undersøgelsen.

\section{Afgransning}

Omfanget af stikprøvens størrelse betyder, at der må foretages en skarp afgrænsning. For det første er analyseenhedernes varighed defineret som minimum 30 sekunder, og alle enheder under 30 sekunder (herunder mange såkaldte skillere, station-ID's og soundbites) er ikke medtaget $\mathrm{i}$ kodningen. Det samme gælder Radioavisen på P1 og timenyhederne på 
Radio24syv, som udgør et særligt format og dermed et forskningsområde for sig. Når en række enheder under 30 sekunders varighed optræder som ét sammenhængende indslag, oprettes en hybridkategori (fx 'oplæsning/reportage').

For det andet kodes kun én gang for hvert program i hver uge, således at den enkelte programtitel kun er repræsenteret med én udsendelse. En vigtig skelnen er her mellem program og udsendelse, for eksempel programmet 'P1 Morgen', som sender alle hverdage mellem kl. 6.05 og 9.00. En udsendelse i dette program er for eksempel 'P1 Morgen' mandag den 16. februar 2015. At der kun kodes én gang for hver programtitel betyder, at alle genudsendelser udgår, og at programmer, der sendes flere gange om ugen, som for eksempel P1's og Radio24syvs morgenprogrammer med fast sendetid hverdage kl. 6.05 til 9.00, kun er repræsenteret med én udsendelse i undersøgelsen.

For at svare på, hvordan udviklingen kan forklares i et institutionelt, regulativt og teknologisk perspektiv, har jeg foretaget en kvalitativ dokumentanalyse af fire former for eksternt kildemateriale: Lovgivning, publikationer, pressemeddelelser og avisartikler. Disse vil jeg gradvist holde op mod resultaterne fra den kvantitative indholdsanalyse.

\section{Kodningskategorier}

Skellet mellem form og indhold er analytisk og indebærer, at kategorierne er blevet defineret ud fra deres formmæssige træk. I alt er der identificeret og defineret 24 formidlingskategorier, hvoraf jeg vil fokusere på disse:

- Oplæsning: Oplæsning af journalistisk og poetisk tekst.

- Interview uden for studiet: Styret samtale, hvor værten spørger, og gæsten svarer.

- Dokumentar: Virkelige historier, der er 'rige på lyd' og kunstnerisk udført.

- Telefoninterview: Styret samtale mellem vært og interviewperson, hvor værten spørger, og interviewpersonen svarer.

- Studieinterview: Interview foretaget i radiostudie.

- Reportage: Tilstedeværelsen af indeksikalsk lyd (dvs. lyd, der indikerer selve lydens kilde eller årsagen), som iscenesætter reporteren - og lytteren - i en given kontekst.

- Hybrid: Sammenklipning af enheder på under 30 sekunder hver (fx oplæsning og reportage).

- Dialog: Dialog i studiet mellem to værter eller vært og gæst.

- Monolog: Monologisk tale (vært eller gæst) i studiet, som ikke er oplæsning.

- Fiktion - drama: Længere, sammenhængende fiktionsfortælling i form af en ikke-live, redigeret skuespilperformance med flere lydspor.

Jeg vil i denne artikel se nærmere på, hvilke af de ovennævnte formidlingsformer, der er blevet markant flere eller færre af. Jeg vil først fokusere på monolog, interviews (studie vs. 
Ikke-studie), reportage og dialog. Dernæst vil jeg analysere udviklingen inden for de monterede former.

\section{Mindre oplæsning, mere monolog}

På P1 er oplæsning næsten halveret (fra 7,9 pct. i 2007 til 3,8 pct. i 2015). Radio24syvs andel af oplæsning (7,0 pct.) er højere i forhold til P1 2015. På P1 er monolog faldet (fra 1,4 pct. til 0,2 pct.). Radio24syvs andel af monolog (0,6 pct.) er marginalt højere i forhold til P1 i 2015.

Dette illustrerer en halvering af oplæsning på P1 og et endnu større fald $i$ andelen af monolog. Radio24syv har knap dobbelt så meget monologisk tale som P1 i dag. Her skal igen tages det forbehold, at det er kompliceret at vurdere forskellen på oplæsning og monolog.

En forklaring på, at der er mere monologisk tale på Radio24syv end på P1 i 2015, kan være, at Radio24syv helt fra kanalens begyndelse har givet taletid til markante værter, som er blevet garant for et bestemt produkts kvalitet. Værtens navn synes i mange tilfælde lige så vigtigt som programmets titel: 'Forfra med Jeppesen' med vært Michael Jeppesen, 'Rushys Roulette' med vært Rushy Rashid, 'Cordua og Steno' med værterne Jarl Cordua og Torben Steno og 'Huxi og det gode, gamle folketing' med vært Huxi Bach, for at nævne nogle få eksempler. Dette kan i øvrigt også være forklaringen på den øgede mængde dialog og debat.

Med faldet af monolog og oplæsning på P1 distancerer kanalen sig både fra den autoritative henvendelsesform og fra det envejkkommunikerende skriftsprog, som ofte domineres af ét syn på verden.

\section{Oplæsning og monolog (\%)}

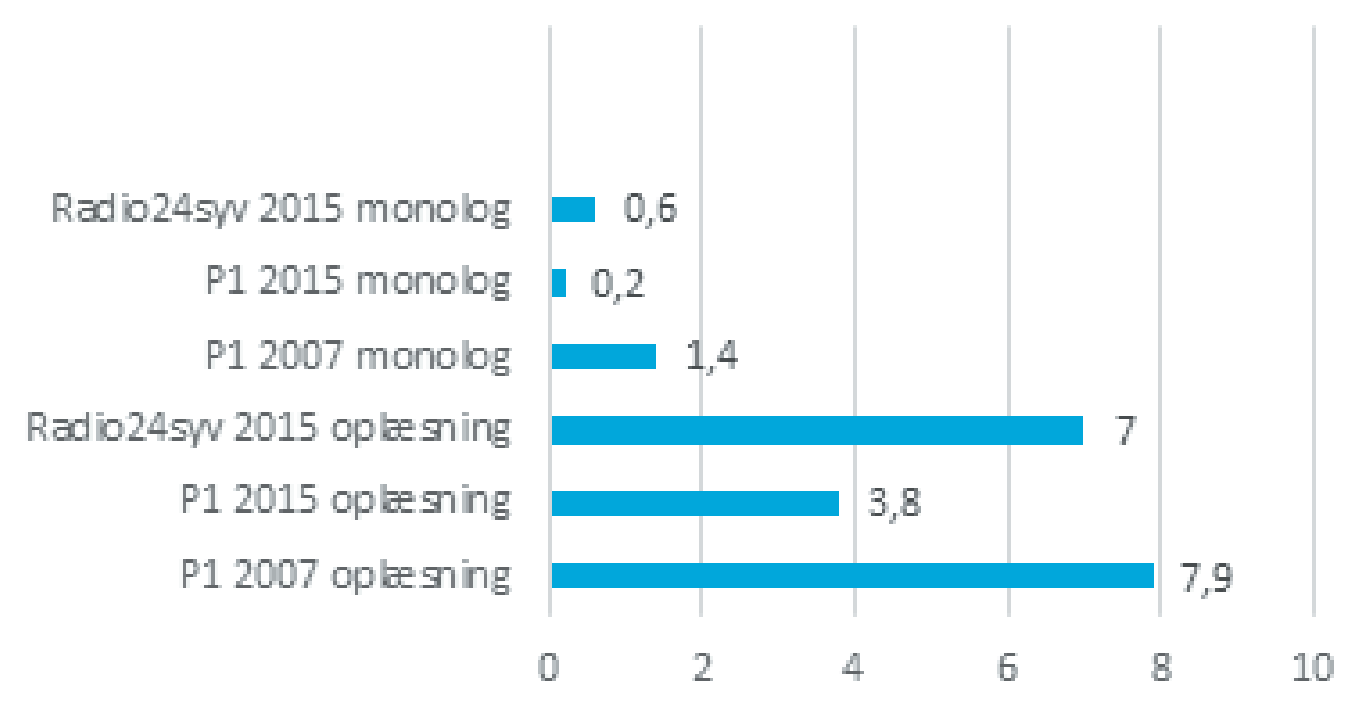

Graf 1: oplesning og monolog 


\section{Mere studieinterview, mindre interview uden for studiet og reportage}

På P1 er andelen af studieinterviews steget markant (fra 14,9 pct. til 32,7 pct.). Omtrent en fjerdedel (26,3 pct.) af Radio24syvs formidlingsformer er studieinterview. Modsat er interview uden for studiet på P1 faldet markant (fra 17,7 pct. til 2,3 pct.). Radio24syv foretager også meget få interview uden for studiet (0,8 pct.). På P1 er telefoninterview steget (fra 8,0 pct. til 14,6 pct.), mens Radio24syv har en andel på 7,9 pct.. På P1 er reportage faldet markant (fra 5,9 pct. til 0,7 pct.), mens Radio24syv's andel er markant højere (6,3 pct.).

En afgørende ændring hos P1 er, at der bruges langt mere tid på interview i studiet og langt mindre tid på interview uden for studiet. Radio24syv sender mere reportage end P1, hvilket med al sandsynlighed skyldes et krav til Radio24syv om at sende 4,5 timers udsendelser i reportageform ugentligt (Kulturministeriet, 2011, p. 4). Dog skal det nævnes, at reportagen, som Radio24syv sender, ofte er forskellig fra P1's. Eksempelvis sender Radio$245 y v$ reportageprogrammet 'Mikrofonholder', hvor to mennesker har en samtale uden for radiostudiet. Lokationen nævnes i udsendelsens begyndelse for at kontekstualisere samtaleemnet, men har derefter ingen eller ringe funktion. Her får reportageformen således nærmere karakter af studiedialog.

Den øgede mængde telefoninterview kan forklares med teknologiske udviklinger, der gør det muligt at broadcaste direkte fra en smartphone uden for studiet. Telefoninterview kan hermed fungere som et billigere alternativ til interview uden for studiet.

Stigningen af studieprogrammer (hovedsageligt studieinterviews) kan skyldes, at både P1 og Radio24syv i 2015 hovedsageligt er defineret som journalistiske kanaler, der kun beskæftiger sig minimalt med æstetik og til hver en tid prioriterer det verbalsproglige og ordenes klarhed over det lydlige og ikke-verbale. Samlet set er studieprogrammerne på P1 (dialog, debat, studieinterview og monolog) steget fra 34,5 pct. til 52,7 pct.. Til sammenligning består Radio24syv af 61,7 pct. studieprogrammer. Dette betyder, at taleradioen i dag indeholder forholdsmæssigt færre indeksikalske lyde.

Studieinterview, interview uden for studiet

\section{og reportage (\%)}

Radio24sy 2015 reportage

P1 2015 reportage

P1 2007 reportage

Radio24sy 2015 interview uden for

P1 2015 interview uden for studiet

P1 2007 interview uden for studiet

Radio24sy 2015 studieinterview

P1 2015 studieinterview

P1 2007 studieinterview

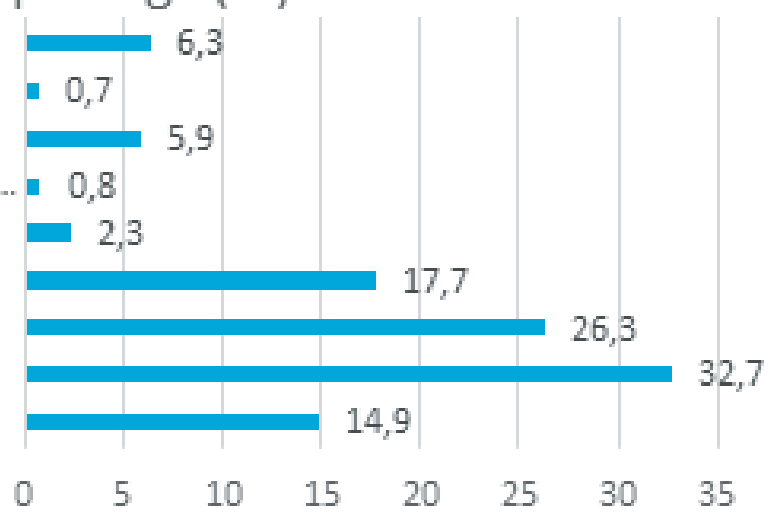

Graf 2: studieinterview, interview uden for studiet, reportage 


\section{Færre hybridformer med to lydspor}

Generelt fremstår P1's formidlingsformer mere bearbejdede end Radio24syv's. Det skyldes, at de kategorier, der rummer to auditive spor, er markant mere repræsenteret på P1 end på Radio24syv. Tilmed benytter Radio24syv ikke oplæsning/telefoninterview, dialog med underlægningsmusik eller -lyd og oplæsning/reportage.

Hvor Radio24syv ikke bruger underlægningsmusik eller -lyd, bruger P1 (2007 og 2015) i høj grad oplæsning med underlægningsmusik - mest konsekvent som start på en programudsendelse efter radioavisen. Over hele ugen i 2007 begynder 20 ud af 33 timer (ca. 61 pct.) med oplæsning med underlægningsmusik efter timenyhederne, og yderligere fem gange optræder oplæsning med underlægningsmusik som det andet element efter timenyhederne. I 2015 på P1 viser sig den samme struktur, hvor 31 ud af 45 timer (ca. 69 pct.) starter med oplæsning med underlægningsmusik.

På Radio24syv begynder kun seks ud af 58 timer (ca. 10 pct.) sådan. Således er radiostationen kendetegnet ved at have en udsendelsesstart uden parallellyd eller -musik, som understøtter det pågældende emne, og ligeledes ved at have en udsendelsesstart, som ikke adskiller sig fra udsendelsens efterfølgende formidlingsform. Indholdsanalysen viser, at oplæsning i starten af en udsendelse ofte går over i en anden form for tale så som dialog, debat og/eller studieinterview.

Udviklingen af formidlingsformerne med to samtidige eller forskudte lydspor illustreres yderligere, når kodningsresultaterne for samtlige hybride formidlingsformer lægges sammen. Oplæsning med underlægningsmusik, oplæsning med underlægningslyd, oplæsning/telefoninterview, dialog med underlægningsmusik eller -lyd, oplæsning/reportage, oplæsning/interview og interview med underlægningslyd udgør tilsammen 12,1 pct. af de samlede formidlingsformer på P1 i 2007. I 2015 er dette tal steget til 16,3 pct. Forskellen fra Radio24syv er markant: Her udgør hybridformerne kun 1,2 pct. af samtlige formidlingsformer.

\section{Mere (direkte) dialog}

Aldrig før er lytterne kommet så meget til orde i public service-medierne som i dag, hvor live-produktionerne fordrer kontinuerlig dialog mellem vært og lyttere. Dialog (enten intern dialog mellem to værter eller en dialog mellem vært og lytter(e)) er på P1 steget fra 7,5 pct. til 11,3 pct., hvor det hos Radio24syv fylder 21,9 pct., altså næsten dobbelt så meget som på P1. Som det ses i det følgende, deler P1 og Radio24syv en fælles strategi omkring at skabe dialog lytterne og værterne imellem, men dette sker altså i praksis i højest grad på Radio24syv.

Den øgede mængde dialog på P1 over de sidste otte år er det konkrete bevis på, at P1 i stigende grad prioriterer live dialog $\mathrm{i}$ stedet for båndede indslag med oplæsning. I en pressemeddelelse den 8. april 2014 forklarer forhenværende kanalchef Anders Kinch-Jensen at P1 får en ny eftermiddagsflade med kulturstof alle hverdage kl. 14-16 og et sammenhængende 
formiddagsprogram kl. 10-12 alle lørdage (DR Presse, 2014a). Der vil desuden blive sendt mere direkte radio for at styrke aktualiteten. Et halvt år efter, den 29. september 2014, er alle programmer på P1 mellem kl. 6 og 18 live (DR Presse, 2014c).

I DR's public service-redegørelser fra 2007 og 2008 bliver dialog og interaktivitet med lytterne ikke nævnt. Til gengæld lægges i DR's mediepolitiske udspil $D R$ - med betydning for alle danskere fra 2009 (DR, 2009a, p. 29) vægt på, at DR fører en dialog med alle brugere i landet, "så danskerne får bedre muligheder for at spille sammen med DR om både de enkelte programmer og mere generelle spørgsmål". Her beskrives det desuden, at DR ønsker at etablere "nye dialogværktøjer, som kan smidiggøre og forbedre danskernes mulighed for at komme i dialog med DR". I 2010 har der ifølge DR selv været en "styrket kontakt og dialog via sociale medier i kraft af DR's stærkere tilstedeværelse på Facebook" (DR, 2011, p. 90). Året efter vurderes det, at institutionen endnu engang har øget sin brug af sociale medier som platform for kontakt og dialog med brugerne (DR, 2012, p. 74). Inddragelsen af nye medier kan yderligere forstås som en del af P1's satsning på de yngre lyttere.

I DR's public service-redegørelse 2012 nævnes hverken dialog eller lytterinteraktion, men i forordet til publikationen DR i 2013 proklamerer generaldirektør Maria Rørbye Rønn og bestyrelsesformand Michael Christiansen, at DR vil efterstræbe "det ambitiøse mål om at styrke den demokratiske samtale og fastholde sammenhængskraften i samfundet". I DR's seneste strategipapir (DR, 2015, p. 2) understreges det, at DR vil understøtte den demokratiske debat ved at gribe de muligheder, som de digitale medier giver.

Målet med denne omlægning af P1 i 2014 synes at være at skabe mere direkte, aktuel radio med formater, hvor to værter guider lytteren fra indslag til indslag, fra historie til historie gennem en hel 'flade'.

En anden forklaring på den øgede mængde dialog på P1 kan findes i et styrket fokus på værtsbåren fladeradio, som det også gælder for Radio24syv. Det er med "kanalens stærke og profilerede værter ved roret" (DR Presse, 2014), at sendingen af et fornyet P1 med mere aktualitet og fladeradio begynder sidst i september 2014. Hermed er både P1's faste morgenprogram og eftermiddagsprogram bestyret af ikke én men to værter. Hverken den værtsbårne radio med to værter eller fladeradio er dog noget nyt fænomen i DR-regi. Allerede i 1991 bemærkede Hanne Bruun og Kirsten Frandsen ('Radioæstetik og analysemetode' i MedieKultur vol. 7, nr. 15, pp. 67-82), at "den generelle tendens inden for DR peger i retning af serviceorienteret fladeradio". Pointen her er, at omlægningen har medført en intensivering af fladeradioformatet med dialog mellem to værter, hvilket også kommer til udtryk i, at der ikke i nogen forudgående pressemeddelelse er blevet lagt vægt på 'stærke' værter med en markant profil. 


\section{Dialog (\%)}

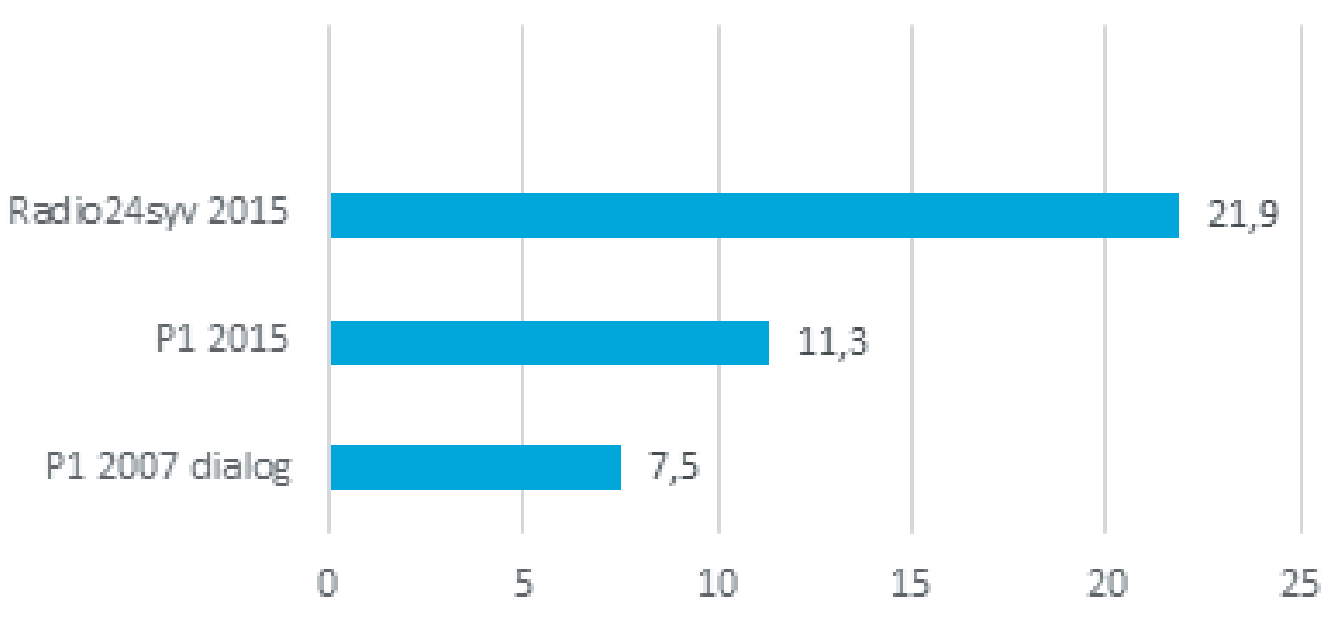

Graf 3: Dialog

\section{Lytterinddragelse}

Ligesom hos P1 er der i Radio24syvs public service-redegørelser lagt vægt på dialog med lytterne. Helt fra stationens start igangsattes lytterinddragelse gennem telefon, SMS, Twitter og Facebook i 10 udsendelsestimer på alle hverdage (Radio24syv, 2012, pkt. 9). Ifølge kanalen selv (Radio24syv, 2015, pkt. 8) udvides "aktiviteterne på sociale medier" i 2012, i 2013 har de fleste programmer implementeret et element af dialog med lytterne, og i 2014 er der i stigende grad gjort brug af Twitter og Facebook.

Den polske medieforsker Karol Jakubowicz er en af få forskere, der har behandlet lytterinddragelse og brugergenereret indhold på public service-kanaler teoretisk. Jakubowicz påpeger $i$ artiklen Public service broadcasting: a new beginning, or the beginning of the end? (Jakubowicz, 2007, p. 20), at når brugerne bliver medskabere (producers) af programindholdet, anerkender public service-institutionerne offentligheden som en aktiv medspiller i stedet for en passiv modtager. Denne lytterinddragelse og dialog med brugerne bliver således public service-mediernes måde at legitimere sig selv på, idet de bliver til offentlighedens og demokratiets medie. Derfor er det kun ved at introducere brugergenereret indhold i programudbuddet - uden at gå på kompromis med dets kvalitet - at public service-medierne kan forblive legitime.

For at det brugergenerede indhold kan implementeres, må public service-institutionerne udvides teknologisk og være til stede på alle platforme. Dette er samtidig et af Jakubowicz' argumenter for, at betegnelsen public service-broadcasting skal ændres til public service-medier (Jakubowicz, 2007, p. 20). I artiklen 'Ny viden om public service' peger Henrik Søndergaard (2010, p. 223) tilsvarende på, at det for public service-medier er en naturlig udvikling at blive modtagerorienterede og få publikum i tale, når konkurrencen 
bliver hårdere. Kun ved at forstå og opfylde publikums løfter kan public service-institutionerne forblive væsentlige og relevante for mere end en mindre del af befolkningen.

De sidste otte år er DR's digitale strategier blevet implementeret på mere omfattende vis, og interaktivitet og sociale medier har i høj grad betydning for formidlingsformerne. Hvad angår DR, kommer interaktiviteten mest markant til udtryk i DR's virksomhedsstrategi 2015-2018, 'Vøerd at dele. Stadig original. Mere digital'. Første del af strategiens undertitel, 'Værd at dele', må forstås sådan, at DR ønsker at levere indhold, der er "værd at være fælles om", som det står i publikationens indledning. Men budskabet kan også læses som en konkret opfordring til den danske befolkning om at dele DR's indhold. Med andre ord satser DR på at producere indhold, der er værd at dele på de nye, sociale medier.

Selvom dette ikke er en direkte forklaring på formidlingsformernes udvikling, tjener strategipapiret som et eksempel på, at DR på alle platforme forsøger at komme i dialog med lytterne/seerne/brugerne (sidstnævnte som medskabere). Den øgede mængde dialog i radioen kan altså også ses i lyset af public service-mediernes generelle, interaktive tilgang til den danske befolkning.

For både P1 og Radio24syv er det altså et direkte mål at inddrage og engagere den almene borger i programmerne gennem dialog mellem to værter, mellem vært og gæst og mellem vært og lytter. Dette kan ses i lyset af udbredelsen af en generel 'mundtlighed' i samfundet samtidig med, at et tab af autoritet finder sted. Som Kirsten Drotner et al. (1996, p. 111) bemærker, kan det faktum, at der er mindre monolog i medierne, skyldes et mere strukturelt autoritetstab, som påvirker alle dele af samfundet. Forholdet mellem den stigende mængde dialog i medierne og et generelt autoritetstab er dog ikke blevet undersøgt videnskabeligt, og sammenhængen er indtil videre blot udokumenterede, men interessante iagttagelser.

\section{Demokratisk selskabelighed}

Ifølge Stig Hjarvard (2005, p. 40) er selve sprogbrugen i medierne blevet mindre formel og kommet tættere på de hverdagslige omgangsformer. Dette måles specifikt hos public service-taleradiokanalerne, som i et forsøg på at undgå, at lytterne slukker for radioen, tilstræber at tale til og med lytterne frem for at tale ned til og om lytterne (Scannel, 1996, p. 24). Denne opfattelse af, at alle i samfundet har samme status, diskursive rettigheder, ret til at udtale sig og ikke mindst noget interessant at sige, kan betegnes som demokratisk selskabelighed.

Men for at en situation opleves som selskabelig, skal den være naturlig, ukompliceret og afslappet (Scannel, 1996, p. 29). Så for at gøre den kontrollerede og unaturlige situation, hvor almindelige mennesker deltager i et radioprogram, mere selskabelig, orienterer public service-kanalerne sig mod de normative værdier i almindelig tale - det vil sige, hvor det at lytte og det at tale er gensidigt udskiftelige (Lacey, 2013, p. 166). Taleren (værten) er - fra tid til anden - lytter og omvendt. 
Med andre ord simulerer P1 og Radio24syv's direkte dialog den selskabelige omgang mellem mennesker. Dette forsøg på at skabe konverserende samtale kan altså læses som en intention om at fremme forståelsen hos lytteren, idet den dialogbaserede samtale er den mest grundlæggende og naturlige kommunikationsform (Scannel, 1996, p. 165).

Selskabeligheden høres ikke blot værter og gæster imellem, men også mellem værter og lyttere. I denne henseende er de nye medier essentielle for udbredelsen af den selskabelige samtale. De skaber mulighed for, at alle kan komme til orde, og brugen af de nye, sociale medier er desuden selvforstærkende, idet brugerne gennem deres deltagelse bekræfter, at den selskabelige samtaleform er den foretrukne (Hjarvard, 2005, p. 40).

Dog viser flere studier (Higgins \& Moss, 1982; Shingler \& Wieringa, 1998), at selvom en lytter er med $\mathrm{i}$ en radioudsendelse, er han/hun ikke i stand til at påvirke den pågældende samtale, fordi hans/hendes kommentarer til hver en tid vil kontekstualiseres og frames af programmet og værten.

Dette pointerer blandt andre medieforskerne Christine Higgins og Peter Moss (1982, p. 33), som har demonstreret, at alle synspunkter, der afviger fra "mainstream-holdningen" $i$ programmet, vil blive undertrykt.

Ligeledes har Martin Shingler og Cindy Wieringa påvist, at selvom phone in-programmer giver lytterne mulighed for at komme til orde, ligger magten hos værten og producenten. Lytterinddragelse er hermed blot en måde, hvorpå programmet kan fremstå mere tilgængelig (Shingler \& Wieringa 1998, p. 124) - og, kunne man tilføje, demokratisk. Radiostationen tegner således et billede af sig selv som en demokratisk instans, der deler deres taletid (og dermed magt) med folket. Men reelt forbliver magten hos radiostationen.

Ifølge Jan Pinseler (2014, p. 65) er denne ulighed mellem værten/producenten og den lytter, der deltager i programmet, snarere en uundgåelig realitet end et demokratisk problem. For på trods af, at lytterne i stigende grad optræder som et selskabeligt og demokratisk element i radioen, er det stadig værten/producenten, der bestemmer, om lytteren må være med - og hvilke betingelser, deltagelsen i så fald skal foregå på.

\section{Produktionsomkostninger}

Sidst men ikke mindst kan et incitament for at lade dialogen fylde være, at formen er økonomisk fordelagtig, idet man som radioproducent ved hjælp af direkte dialog og debat ikke har udgifter til redigering. Det kan også udledes af DR's mediepolitiske udspil 2009 (2009a, p. 22), at dialog med brugerne er besparende. Her konstateres, at "fokus i den samlede omstillingsproces [en årlig besparelse på 300 mio. kroner] har været at omlægge organisationen, så brugerne nu i langt højere grad er i centrum for hele DR's arbejde".

Således kan man argumentere for, at der er en klar sammenhæng mellem de økonomiske besparelser og formidlingsformerne, men det er lige så vigtigt at huske, at teknologien og fremkosten af nye medier giver public service-institutionerne mulighed for at lade brugerne være medskabere af indholdet. Sammenfattende kan det foreslås, at public service-institutionerne har både et direkte (officielt) og et indirekte (uofficielt) formål med 
opgraderingen af dialog og live-radio. Det direkte formål er lytterinvolvering, mens det indirekte formål er besparelse.

Dialog har til formål at gøre radioprogrammet inkluderende. Men kan dialogformen lige såvel opleves ekskluderende, $\mathrm{fx}$ af de brugere, som ikke ønsker at generere indhold? $\mathrm{Og}$ fordrer stigningen af dialog og lytterinddragelse et tilsvarende fald i kvaliteten? Spørgsmål som disse synes ekstra vigtige, når dialogen er steget så markant som bevist $\mathrm{i}$ indeværende undersøgelse.

\section{Færre monterede former (dokumentar og radiodrama)}

Hvad der derimod er blevet markant mindre af i public service-taleradioen, er de monterede formidlingsformer. På P1 er dokumentar faldet fra 10,92 pct. i 2007 til 3,7 pct. i 2015. Radio24syv sender kun 1,7 pct. dokumentar i 2015. I uge 82007 kunne man høre 30 minutters (1,19 pct.) radiodrama på P1. I uge 82015 er der ingen radiodramaudsendelser på public service-radiostationerne. Den traditionelle kunstneriske montage, som 'DokumentarZonen' og 'Ultralyd' repræsenterer, er kun en del af dokumentarindholdet på P1 i 2007 og altså ikke i 2015.

Den åbenlyse forklaring på, at der er kommet en væsentligt mindre andel dokumentar på P1, er nedlæggelsen af montageafdelingen og de to programmer, 'DokumentarZonen' og 'Ultralyd'. På Radio24syv findes et enkelt dokumentarprogram, '24syv Dokumentar', som udgør 1,7 pct. af det samlede udtryk. Radio24syv sender altså mindre dokumentar end P1, hvilket kan forklares med de høje produktionskrav, der er stillet til Radio24syv (Kulturministeriet, 2011). Disse skaber dårlige forudsætninger for tidskrævende produktioner så som dokumentar og montage. Der findes ikke monterede, fiktive fortæellinger på Radio24syv, hverken i form af radiodrama eller sketches af minimum 30 sekunders varighed.

Fraværet af radiodrama på P1 i 2015 skyldes, at DR Drama har lanceret et digitalt univers med navnet 'Drama \& bog' (DR's public service-redegørelse, 2014, p. 9), hvor alle radiodramaproduktioner fremover bliver tilgængelige, og radiodrama er dermed ikke længere at finde som en del af P1. Platformen blev lanceret efter, at stikprøven fra 2015 blev foretaget, men allerede fra årets begyndelse blev radiodramaet ekskluderet i sendeplanen, hvorfor det også er fraværende i uge 8.

Udviklingen bør dog ses i lyset af, at DR siden 2008 har omstruktureret ressourcerne til produktion af tv og radio. Af DR's omkostninger til egenproduktion i 2007 gik 53 pct. til tv (to analoge og en digital kanal), 5 pct. på nye medier og 41 pct. til de fire FM-kanaler og 14 DAB-kanaler (DR, 2008, p. 42). I 2013 var omkostningerne fordelt med 62 pct. på seks tv-kanaler, 8 pct. på nye medier, 8 pct. på orkestre og kor og 22 pct. på 11 radiokanaler (DR, 2014a, p. 15). Ifølge disse tal er omkostninger til egenproduktion af radio altså blevet halveret, siden besparelserne trådte $\mathrm{i}$ kraft.

Den generelle negligering af nichegenrer, så som montagen og radiodramaet, på både P1 eller Radio24syv, er modstridende til, hvad Jakubowicz (i Mortensen, 2008, p. 276) kalder 
en af public service-institutionernes mest centrale opgaver, nemlig at korrigere og udfylde mangler i den kommercielle sektor. På den vis kan man hævde, at for eksempel nedlæggelsen af montageafdelingen er en misvedligeholdelse af de public service-krav, der er indbefattet i Jakubowicz' public service-opfattelse.

Dertil skal nævnes, at regeringen bag det nuværende medieforlig har besluttet, at pr. 1. januar 2015 skal alle med apparater, der kan modtage og gengive tjenester udsendt til almenheden - det vil i praksis sige alle med en smartphone - betale licens.

\section{Hvem boerer ansvaret?}

Man må dog også holde sig for øje, at eftersom P1 og Radio24syv er licensfinansierede og dermed betalt af offentlige midler, må public service-medierne nå ud til så mange licensbetalere - dvs. alle, der blot ejer en smartphone (Kulturministeriet, 2014b, p. 10) - som muligt.

I DR's public service-kontrakt for 2007-2010 (DR, 2009b, p. 1) står det anført, at DR "af demokratiske, sociale og kulturelle grunde skal have de nødvendige ressourcer til rådighed samt ret og pligt til at tilbyde public service-indhold på alle relevante platforme til hele befolkningen". Dog bliver 'de nødvendige ressourcer' fastlagt af staten, og public serviceinstitutionerne må tilpasse sine udgifter herefter. Frands Mortensen (i: Carstensen et al., 2007, p. 177) definerer således ikke public service-kontrakten som en ligeværdig aftale mellem to aktører, men rettere som den enes fastlæggelse af den andens opgave. Grunden til, at staten ikke følte sig forpligtet til at yde økonomisk hjælp til DR, som i stedet måtte igangsætte besparelser fra 2008 og tre år frem, er ifølge Mortensen, at der er "vage forestillinger om, hvad det skal koste at opfylde [public service-opgaven]", fordi denne ikke er klart defineret (Carstensen et al. 2007, p. 177). Kulturministeriet mente, at der var penge nok til at løse opgaven, hvilket der i realiteten ikke var. Situationen forværredes yderligere, da kontrollen med DR's løsning af public service-opgaven - herunder opførelsen af det nye DR Byen - ligeledes var vag. I forlængelse heraf kan man derfor argumentere for, at DR og Radio24syv ikke egenrådigt er ansvarlige for, at montagen ikke produceres i public serviceregi i dag.

Henrik Søndergaard (2010, p. 238) argumenterer for, at det er igennem en offentlig debat, at public service-institutionerne kan legitimeres og vinde befolkningens opbakning. Som Jakubowicz (i Mortensen 2008, p. 275) fremfører, har public serviceinstitutionerne da vundet en magtfuld allieret, én der vil forhindre regeringer i at gennemføre en politik, der marginaliserer, svækker og eliminerer public service-medierne. Her tjener montageafdelingens nedlæggelse som et eksempel på det modsatte.

\section{Ensretning af formidlingsformerne på P1 og Radio24syv}

Når det gælder formidlingsformerne, minder P1 i dag mere om Radio24syv end sig selv i 2007. Et illustrativt eksempel er studieinterviewet, som hos P1 er steget fra 14,9 pct. til 26,3 pct. og dermed ligger væsentligt tættere på Radio24syv's 32,7 pct. Stigningen i studieinter- 
view modsvarer faldet i interview uden for studiet, hvor P1 (2,3 pct.) i dag ligger væsentligt tættere på Radio24syv (0,8 pct.) end sig selv i 2007 (17,8 pct.). Hvad angår dokumentar, er procentandelene hos begge kanaler så lave, at de i 2015 (P1 3,7 pct., Radio24syv 1,7 pct.) tilsammen udgør under halvdelen af kategoriens andel på P1 i 2007 (10,9 pct.).

Hermed bliver det tydeligt, at Radio24syv i hvert fald kvantitativt ikke udfylder det rum, som opstod efter nedlæggelsen af montageprogrammerne på P1 ved årsskiftet i 2008. I denne optik har tilkomsten af Radio24syv dermed umiddelbart betydet, at der er kommet formmæssigt mere af det samme. Dette kan enten skyldes, at de to kanaler uafhængigt af hinanden bevæger sig i samme retning og dermed nærmer sig hinanden, eller at den ene kanal retter sig mod den andens formater. I lyset af P1's omfattende omlægning i 2014 synes det mest sandsynligt, at det er P1, der bevæger sig i retning mod Radio24syv.

I 2015 er de tre største kategorier telefoninterview, studieinterview og dialog på P1 (58,6 pct.), mens debat, interview uden for studiet og studieinterview er de dominerende kategorier på P1's sendeflade i 2007 (43,1 pct.). De mest dominerende kategorier udgør altså en større andel af samtlige formidlingsformer på P1 i 2015 end i 2007. Denne ensretning af formidlingsformerne samt det faktum, at radiofiktion ikke måles på P1's sendeflade i 2015, peger i retning af, at formidlingsformerne er mere ensformige på P1 i 2015 end i 2007.

Radio24syv har dog det mest ensformige udtryk, hvor debat, studieinterview og dialog dominerer (61 pct.). I lyset af at produktionskravene til Radio24syv er mere specificerede end på $\mathrm{P} 1$, kan det foreslås, at jo mere specificerede produktionskrav des mindre eksperimenteres der med formen.

\section{Leverer P1 og Radio24syv bred eller smal public service?}

I 2005 udgiver DR et mediepolitisk udspil for perioden 2007-2010, DR for dig og hele Danmark, hvori det betones, at den nationale mangfoldighed er en kerneværdi, og at DR "skal være noget at samles om", "være relevant for alle danskere" og "et livskraftigt demokrati" (DR 2005, p. 11). På dette tidspunkt opfatter DR sig selv som et kulturelt integrerende public service-medie, hvis kerneopgave er formidling af national kultur, der skal vedligeholde og integrere fællesskabet. Også i DR's public service-redegørelse 2008 er mangfoldigheden i fokus:

Formålet med DR's samlede programudbud er at tilfredsstille de mange forskellige interesser og behov i den danske befolkning. Med andre ord at sikre mangfoldigheden for de enkelte programmer, genrer og kanaler. Desuden har DR et særligt fokus på at spejle mangfoldigheden $i$ det danske samfund og lave programmer og tjenester, hvor alle grupper er reprcesenteret. (DR, 2009b, p. 44)

Samtidig ønsker DR at være et "stærkt alternativ til de kommercielle og udenlandsk dominerede radio- og musiktilbud, som i stigende grad vokser frem på nettet" (DR, 2009b, p. 46). DR vil altså ikke blot differentiere sig fra det kommercielle marked ved at tilbyde indhold, som det kommercielle marked ikke leverer, men også konkurrere om de danske seere 
og lyttere ved at tilbyde et bredt appellerende indhold. I DR's mediepolitiske udspil fra 2009 (DR, 2009a, p. 5) kan man endvidere læse, at "kun hvis vi har bredt fat i danskerne, kan vi konstant blive ved med at udfordre og oplyse med succes og have betydning for alle danskere. (...) Ellers er det kun udvalgte grupper, som deltager i den nationale samtale, og dermed begrænses demokratiet".

Denne modtagerorienterede strategi - en vision om at være dér, hvor lytterne er (DR, 2015b) - kommer direkte til udtryk i de institutionelle beslutninger vedrørende P1 siden 2007. Her tænkes i særlig grad på nedlæggelsen af smalle, omkostningstunge programmer som 'DokumentarZonen' og 'Ultralyd' og opprioritering af live, aktuel fladeradio.

Også Radio24syv ønsker, at kanalens indhold når bredt ud til befolkningen. På Radio24syvs hjemmeside formuleres det, at kanalens mission er at være en folkelig og mangfoldig radiokanal og gå imod den stigende fragmentering og segmentering i samfundet. Ifølge Tillægsaftale til den mediepolitiske aftale for 2011-14 af 26. maj 2010 om valg af programprofil for den fjerde landsdækkende FM-radiokanal (Kulturministeriet, 2010b) har Radio24syv til formål at være "en bredt appellerende og nyskabende nyheds- og tale-radio", hvorfor dannelsen af Radio24syv udtrykker et ønske om at sikre, at hele befolkningen får noget for licenspengene ved at bryde med DR's monopol på radioområdet.

Samtidig er public service-området blevet udvidet i takt med, at DR og Radio24syv har integreret online tjenester i deres virksomhed. At institutionerne justeres i forhold til den nye digitale virkelighed er endnu et tegn på, at P1 og Radio24syv ønsker at levere bred public service til hele befolkningen ved hjælp af tilgængeliggørelse og mangfoldighed i programudbuddet. Både DR og Radio24syv ser det som en nødvendighed at være brede og modtagerorienterede.

Nærværende kvantitative undersøgelse af formidlingsformerne på P1 og Radio24syv viser et billede, der ikke svarer til kanalernes beskrivelser af sig selv. Her er flere formidlingsformer forsvundet fra P1 - deriblandt montagen, radiodramaet og interviewet uden for studiet - og ensretningen af de to kanaler tyder på, at tilkomsten af Radio24syv ikke har medført et bredere programæstetisk eller formmæssigt udbud. Den stigende konkurrence samt et ønske om at nå bredt ud har altså paradoksalt nok medført et mere ensrettet udbud af formidlingsformer. Public service-taleradioen er i den forstand blevet mere smal i perioden 2007 til 2015.

I stedet for at prioritere smalt indhold til den brede befolkning, som det for eksempel kunne gøres ved at gøre nicheprogrammer mere synlige, har P1 prioriteret det brede public service-indhold. Både P1 og Radio24syv forsøger at nå bredt ud gennem en ensartet formidling, men igen må man ikke glemme, at Radio24syvs public service-krav kvantitativt og kvalitativt er mere specificerede, end de er for P1, der som konsekvens nyder større programmæssig frihed. 


\section{Radioens lydlige potentialer og selvstændige podcastproduktioner}

Analysen i denne artikel viser, at public service-institutionerne i 2015 som udgangspunkt allokerer få ressourcer til at udvikle og eksperimentere med radioens lydlige muligheder. Artiklen har desuden argumenteret for, at forklaringen skal findes i offentlige og institutionelle reguleringer og en stigende tendens til at vægte aktualitet, lytterengagement og lytterinteraktivitet højere end det kunstneriske.

Situationen er en anden uden for DR og Radio24syv, hvor der inden for det sidste årti er opstået en lang række kreative radioproduktioner med fokus på radio som kunst. Den tidsforskudte lytning på en mobil enhed - at podcaste - giver større mulighed for at vælge produktet til, når der er tid og ro til at lytte. Samtidig indebærer podcastformatet en frisættelse af formerne af den grund, at radioprogrammets længde og indhold ikke skal passe ind i en flade eller en bestemt kanalprofil, og at alle med adgang til en mikrofon har mulighed for at være producenter.

Det vil være oplagt at foreslå, at det netop er digitaliseringen og formaternes frisættelse, der har været drivkraften bag "podcastens guldalder", som nutiden er blevet betegnet (Yde 2014). Den teknologiske udvikling har først og fremmest medført, at etablerede medier som DR og Radio24syv ikke længere er nødvendige led i skabelsen og distributionen af radiofonisk materiale, fordi professionelle og amatører uden for public service-regi på egen hånd relativt nemt kan eksperimentere med og udgive podcasts.

Men man kan også se på podcastformatets succes ud fra Chris Andersons teori (2006), at jo større udbud desto større efterspørgsel. Netop podcastens uendelige muligheder skaber et uendeligt behov hos lytterne, men medievirksomhederne kan ikke længere regne med mange millioner seere og lyttere, for de tiltrækkes nemt af andre tilbud. Massemarkedet bliver suppleret af en masse af nicher (Anderson, 2006, 5), hvor public service-institutionerne må dele lytternes opmærksomhed med mange tusinde ind- og udenlandske podcastproduktioner.

Selvom de fleste danskere i 2016 kan erhverve sig optageudstyr og klippeprogrammer, er radiomontagen dog, ifølge professor lb Poulsen (i: Strøyer, 2008), stadig afhængig af at have en institution som DR bag sig på grund af dens tidskrævende optagelser og postproduktion. Dette kan også ses som noget af forklaringen på, at Kunstrådets Litteraturudvalg den 30. januar 2008 offentliggjorde, at udvalget fremover vil give støtte til mundtlig litteratur og æterbåren kunst, herunder radiomontagen (Strøyer, 2008). Godt syv år senere tildelte Statens Kunstfond for første gang et 3-årigt arbejdslegat til podcastmagasinet 'Third Ear', som blev startet i 2009 af blandt andre montagekunstnere fra det nedlagte P1-program 'Ultralyd'. Statens Kunstfonds Legatudvalg for Litteratur begrunder valget med podcastmagasinets "vedholdenende produktion af kompromisløst eksperimenterende og stemningsfulde radiomontager" (Statens Kunstfond Presse, 2015). Med Statens Kunstfond i ryggen bliver det dermed muligt for private virksomheder at udnytte det frirum, der opstår, når public service-institutionerne ikke producerer kunstnerisk og eksperimenterende radio. 
'Third Ear' er ikke det eneste initiativ, der skaber forskelligartede historier i lyd, og som finder en alternativ indkomstmulighed, der gør foretagendet muligt. Trendmagasinet 'Soundvenue' har lanceret podcasten 'Soundvenue Filmcast', mens platformen 'Re:Cast' udgiver nye, ukendte radioproduktioner, hvor lytteren kan donere penge til producenten. 'Københavns Radiobiograf' har uovertruffen stor publikumstilslutning til sine udsolgte arrangementer. Eventet er desuden et eksempel på, at radiolytning i dag bruges som en primær og ikke blot en sekundær aktivitet i de danske storbyer.

Dog er der stadig et stykke vej igen, før Danmark befinder sig i 'podcastens guldalder'. Vendes blikket mod USA, bemærkes det, at amerikanske podcastproducenter finansieres af sponsorater og frivillige donationer fra lytterne. Dette gælder også for den offentlige, amerikanske radiostation NPR (National Public Radio), som står bag gigantsuccessen 'Serial' fra efteråret 2014 (Berry, 2015). Herhjemme er produktionen af eksperimenterende, tidskrævende radioprogrammer en opgave, som ligger andre aktører end public serviceinstitutionerne på sinde, heriblandt førnævinte 'Third Ear', og som bliver muliggjort gennem statsstøtte. Hermed ses en form for polarisering af taleradioens formidlingsformer: public service-medierne laver demokratisk, interaktiv live-radio, mens uafhængige podcastproducenter med støtte fra staten udforsker radioens lydlige potentialer.

\section{Konklusion og perspektiver for videre forskning}

Denne artikel kortlægger udviklingen af formidlingsformerne i den danske public servicetaleradio og bidrager dermed med ny viden til et felt, som er underrepræsenteret inden for akademisk forskning (Chignell, 2009, p. 1, Lejre \& Kristensen, 2014, p. 152). En kvantitativ indholdsanalyse af P1 i uge 8 i 2007 og af P1 og Radio24syv i uge 8 i 2015 viser, at en stor del af DR's autoritative, monologiske oplæsning er blevet erstattet med dialog. Andelen af dialog på Radio24syv i uge 8, 2015 er dog dobbelt så stor som hos P1. Dialogen består både af 'intern' dialog mellem værter og 'ekstern' dialog mellem public service-institutionerne og brugerne/lytterne. Generelt er der kommet flere studieprogrammer i den danske public service-taleradio, og der foretages færre interviews uden for studiet og færre reportager samtidig med, at mængden af studieinterviews er steget markant. Der registreres en nedgang i public service-taleradioens æstetiske formater, så som radiomontagen og radiodramaet.

For at nuancere forklaringen på denne udvikling af formidlingsformerne på P1 og Radio24syv er der foretaget en kvalitativ analyse af public service-institutionernes og Kulturministeriets offentlige dokumenter inden for udvælgelsesrammen 2007-2015. Dokumentanalysen viser, at P1 og Radio24syv først og fremmest definerer deres public service-opgave som et forum for dialog og debat. De tidskrævende, monterede formater er underordnet lytterinddragelse, aktualitet og live-sending, hvormed der ses en ensretning af formidlingsformerne på de to kanaler. P1 etablerer sig i stigende grad som en nyheds- og aktualitetskanal, hvilket stemmer overens med Radio24syvs programprofil. P1 og Radio- 
24syv konkurrerer på aktualitet og lytterorientering frem for at prioritere at gøre formidlingsformerne forskellige fra dem, som kommercielle medier benytter sig af.

Dermed peges der på, at både DR og Radio24syv kan defineres som leverandører af bred public service. Siden 2007 er dansk public servicetaleradio altså på samme tid blevet bredere, fordi kanalerne forsøger at nå hele befolkningen gennem brugerorienterede programmer, og smallere, fordi kanalernes formidlingsformer er blevet reduceret. Det indikerer, at det ikke er den danske public service-taleradio, der i den nærmeste fremtid kommer til at introducere nye (æstetiske) radioformater. Derimod kommer den eksperimentelle udvikling formodentlig til at ske i privat podcastregi.

Undersøgelsens resultater er et udtryk for formidlingsformerne i to fortløbende uger (uge 8 i 2007 og uge 8 i 2015) og er ikke en repræsentativ stikprøve foretaget over en længere periode - heller ikke selvom de to udvalgte uger er set fri for særlige begivenheder og højtider, der kan påvirke det empiriske materiale. Stikprøven har ikke indfanget de formmæssige variationer, der vil være fra udsendelse til udsendelse inden for den enkelte programtitel, og det vil derfor være oplagt at foretage en ny undersøgelse, hvor der kodes for samtlige sendetimer på de pågældende kanaler $\mathrm{i}$ de pågældende uger.

Undersøgelsens fremgangsmåde giver rum til mere omfattende og repræsentativ forskning af radiomediets formidlingsformer. Ivrige radiolyttere havde måske haft en formodning om, at der var kommet flere live-programmer og mere dialog-tale i radioen over de seneste år, men denne udvikling er ikke før blevet dokumenteret på indslagniveau. Et andet aspekt, som kun kort er blevet nævnt i denne artikel, og som indeholder omfattende forskningsperspektiver, er den udokumenterede, men omtalte sammenhæng mellem dialog $\mathrm{i}$ medierne og et autoritetstab $\mathrm{i}$ befolkningen som helhed. Tanken kan $\mathrm{fx}$ belyses gennem ekspertinterviews med kanalchefer og en dybdegående undersøgelse af lytternes/seernes oplevelser af autoriteter i medierne.

\section{Litteratur}

Anderson, C. (2006). The Long Tail. How Endless Choice is Creating Unlimited Demand. London: Random House Business Books.

Berry, R. (2015). A Golden Age of Podcasting? Evaluating Serial in the Context of Podcast Histories. Journal of Radio \& Audio Media, 22:2, 170-178.

Bruun, H. \& Frandsen, K. (1991). Radioæstetik og analysemetode. MedieKultur vol. 7, nr. 15, 67-82.

Carstensen, M.B., \& Svith, F., \& Mouritsen, P. (2007). DR og TV2 - i folkets tjeneste. Århus: Forlaget Ajour.

Chignell, H. (2009). Key Concepts in Radio Studies. London: SAGE Publications Ltd.

Drotner, K, \& Jensen, K.B., \& Poulsen, I., \& Schrøder, K (1996): Medier og kultur. Valby: Borgens Forlag.

Eskjær, M.F. \& Helles, R. (2015). Kvantitativ indholdsanalyse. Frederiksberg: Samfundslitteratur.

Higgins, C.S.C., \& Moss, P.D. (1982). Sounds Real. Radio in Everyday Life. St. Lucia: University of Queensland Press.

Hjarvard, S. (2005). Det selskabelige samfund. Essays om medier mellem mennesker. Frederiksberg: Forlaget Samfundslitteratur. 
Høgh, K. (2010). Medier der holder - strategisk lyd- og videopodcasting. Frederiksberg: Forlaget PodConsult. Jakubowicz, K. (2007). Public service broadcasting: a new beginning, or the beginning of the end? KnowlegdePolitics. Theory and practice for the information society.

Jauert, P. (2010). Radioen og den digitale udfordring. I T. Broddason, U. Kivikuru, B. Tufte, L. Weibull \& H. Østbye (red): Norden och världen. Perspektiv från forskningen om medier och kommunikation. Göteborg: Göteborgs Universitet.

Kreutzfeldt, J. (2015). Radioverdener. Auditiv kultur, historie og arkiver. Århus: Aarhus Universitetsforlag. Lacey, K. (2013). Listening Publics. The Politics and Experience of Listening in the Media Age. Cambridge: Polity Press.

Lejre, C, \& Kristensen, N.N. (2014). En kvantitativ metode til analyse af radio. MedieKultur vol. 30, nr. 56, 151-169

McLuhan, M. (1964). Understanding Media. The Extensions of Man. New York \& London: Routledge.

Mortensen, F. (2008). Public service i netvcerkssamfundet. Frederiksberg: Forlaget Samfundslitteratur.

Shingler, M., \& Wieringa, C. (1998). On Air. Methods and Meanings of Radio. London: Arnold.

Scannell, P. (1996). Radio Television and Modern Life. London: Blackwell.

Søndergaard, H. (2010). Ny viden om public service. I E. N. Svendsen (Eds.), Public service - i praksis og i fremtiden (215-240). Århus: Forlaget Ajour

\section{Dokumenter}

DR (2005). DR for dig og hele Danmark. Ønsker og løfter til Mediepolitisk aftale 2007-2010. København: DR DR (2008). DR's årsrapport 2007. København: DR

DR (2009a). DR's mediepolitiske udspil. DR - med betydning for alle danskere. København: DR

DR (2009b). DR's public service-redegørelse 2008. København: DR

DR (2010). DR's public service-redegørelse 2009. København: DR

DR (2011). DR's public service-redegørelse 2010. København: DR

DR (2012). DR's public service-redegørelse 2011. København: DR

DR (2014). Fakta om P1 2013. København: DR

DR (2015a). Medieudviklingen 2014. København: DR

DR (2015b). DR's virksomhedsstrategi 2015-2018: Værd at dele. Stadig original. Mere digital. København: DR Kulturministeriet (2010a). Forslag fra det hurtigt arbejdende udvalg vedrørende nærmere fastlæggelse af programprofilen for den fjerde landsdækkende FM-radio-kanal. København: Kulturministeriet

Kulturministeriet (2010b). Tillægsaftale til den mediepolitiske aftale for 2011-14 af 26. maj 2010 om valg af programprofil for den fjerde landsdækkende FM-radiokanal. København: Kulturministeriet

Kulturministeriet (2011a). Tilladelse til programvirksomhed på den fjerde jordbaserede FMradiokanal.

København: Kulturministeriet

Kulturministeriet (2014a). DR's Public Service-kontrakt for 2015-2018. København: Kulturministeriet

Kulturministeriet (2014b). Mediepolitisk aftale 2015-2018. København: Kulturministeriet Kulturministeriet

(2014c). Mediernes udvikling i Danmark 2014 - Radio. København: Kulturministeriet

Radio24syv (2012). Radio24syv's public service-redegørelse 2011. København: Radio24syv

Radio24syv (2015). Radio24syv's public service-redegørelse 2014. København: Radio24syv

\section{Avisartikler}

Andersen, C. (2014, 3. december): Radio: Amerikansk mordserie suger lyttere til sig. Politiken. http://politiken. dk/magasinet/feature/ECE2473032/radio-amerikansk-mordserie-suger-lyttere-til-sig/ (hentet 25.09.15). 
Brovall, S. (2013, 10. maj): Nu skal radio høres i biografen. Politiken. http://politiken.dk/kultur/filmogtv/ ECE1966300/nu-skal-radio-hoeres-i-biografen/ (hentet 25.09.15).

Strøyer, R. (2008, 30. januar): Radiomontagen får kunstigt åndedræt. Politiken. http://politiken.dk/kultur/ ECE465099/radiomontagen-faar-kunstigt-aandedraet/ (hentet 25.09.15).

Yde, K.H. (2014, 17. november): Mennesket i podcastens guldalder. Information. http://www.information. $\mathrm{dk} / 516013$ (hentet 25.09.15).

\section{Pressemeddelelser}

DR Presse (2014, 8. april). P1 får mere aktualitet og ny kultureftermiddag: https://www.dr.dk/DRPresse/Artikler/2014/04/08/115240.htm?wbc_purpose=1 (konsulteret 25.09.15)

DR Presse $(2014,8$. september). DR omstiller til ny medievirkelighed.

http://www.dr.dk/Om_DR/Nyt+fra+DR/artikler/2014/09/08111531.htm (konsulteret 25.09.15)

DR Presse (2014, 24. september). Et fornyet P1 går i luften.

https://www.dr.dk/drpresse/artikler/2014/09/23/134241.htm (konsulteret 25.09.15)

DR Presse (2015, 27. april). Radiodrama går digitalt:

https://www.dr.dk/DRPresse/Artikler/2015/04/23/151008.htm (hentet 25.09.15)

Kulturministeriet Presse (2010, 10. september). Nyskabende radio på FM4: http://kum.dk/nyheder-ogpresse/pressemeddelelser/nyheder/nyskabende-radio-paa-fm4/1/1/ (konsulteret 25.09.15)

Statens Kunstfond $(2015,25$. maj). For første gang modtager tegneserieskabere og radiomontagekunstnere treårige arbejdsstipendier fra Statens Kunstfond:

://www.anpdm.com/newsletterweb/4345514B77455435A4277474559/42415C4B7642405C407 448435A43

(konsulteret 25.09.15)

Freja Sørine Adler Berg

MA student

Department of Media, Cognition and Communication

University of Copenhagen

frejasorine@gmail.com 